Revista Brasil. Bot., V.34, n.3, p.285-295, jul.-set. 2011

\title{
Green algal interactions with physicochemical parameters of some manmade ponds in Zaria, northern Nigeria
}

\author{
MATHIAS AHII CHIA ${ }^{1,2,3}$, SUNDAY PAUL BAKO ${ }^{1}$, SAMSON O. ALONGE ${ }^{1}$ and \\ ABU KASIM ADAMU ${ }^{1}$
}

(received: October 5, 2010; accepted: April 6, 2011)

\begin{abstract}
Green algal interactions with physicochemical parameters of some manmade ponds in Zaria, northern Nigeria). Green algal species and their association with physicochemical parameters in some manmade ponds in Zaria, Nigeria were studied from November 2005 to August 2006. Phytoplankton and water samples were collected, preserved and analyzed using standard methods. A total of 27 green algal species divided into 16 families were recorded. Shannon diversity indices ranged from 1.75 to 2.39 in all ponds, dominance index from 0.14 to 0.23 and species evenness 0.56 to 0.64. Closterium sp. and Rhizoclonium hookeri Kuetz. were positively associated with the concentration of Fe, however they were negatively correlated (sensitive) to alkalinity, total dissolved solids and electrical conductivity. Stichococcus bacillaris Naegeli, Staurastrum rotula Nordst. and Sphaeroplea sp. had significant positive relationship with biochemical oxygen demand (BOD), Mn, and Mo levels in the water. Pseudouvella americana (Snow) Wille. and Scenedesmus quadricauda (Turp.) de Bréb. showed a close positive association with alkalinity but were sensitive to Fe, BOD, Mn and Mo. The species reported here showed closed association with physicochemical factors in these ponds.
\end{abstract}

Key words - Chlorophyta, diversity, ecology, lenthic water bodies, trace metals

RESUMO - (Interação de algas verdes com parâmetros físico-químicos em lagoas artificiais em Zaria, Norte da Nigéria). As espécies de algas verdes e sua associação com parâmetros físico-químicos em lagoas artificiais de Zaria, Nigéria foram estudados entre novembro de 2005 e agosto de 2006. As amostras de fitoplâncton e de água foram coletadas, preservadas e analisadas usando métodos padrões. Foram registradas um total de 27 espécies de algas verdes divididas em 16 famílias. Os indices de diversidade de Shannon variaram de 1,75 a 2,39 em todas as lagoas; índice de dominância de 0,14 a 0,23 e a eqüidade de espécies de 0,56 a 0,64. Closterium sp. e Rhizoclonium hookeri Kuetz. foram associados positivamente com a concentração de $\mathrm{Fe}$, porém eles foram correlacionados negativamente (sensíveis) à alcalinidade, condutividade elétrica e sólidos totais dissolvidos. As espécies Stichococcus bacillaris Naegeli, Staurastrum rotula Nordst. e Sphaeroplea sp. tiveram relação positiva e significativa com a demanda bioquímica de oxigênio, e com os níveis de Mn e Mo na água. Pseudouvella americana (Snow) Wille. e Scenedesmus quadricauda (Turp.) de Bréb. mostraram estreita associação positiva com a alcalinidade, mas foram sensíveis ao $\mathrm{Fe}, \mathrm{DBO}, \mathrm{Mn}$ e Mo. As espécies relatadas aqui apresentaram associação próxima com fatores físico-químicos nessas lagoas.

Palavras-chave - Chlorophyta, diversidade, ecologia, corpos d'água lênticos, metais-traço

\section{Introduction}

Ponds constitute an ecosystem that supports a wide array of organisms ranging from lower plants to higher plants. In some developing countries they are a contributing source of water for domestic use such as washing of cloths, bathing and sometimes as a source of drinking water (Chia et al. 2009a). The distribution and abundance of microalgae in this system are controlled by a wide range of physical, chemical and biological factors. Trace elements are essential for metabolic processes in

1. Universidade Federal de São Carlos, Centro de Ciências Biológicas e da Saúde, Departamento de Botânica, Laboratório de Biotecnologia de Algas, Caixa Postal 676, 13565-905 São Carlos, SP, Brazil.

2. Ahmadu Bello University, Department of Biological Sciences, PMB 1013, Postal Code 810001, Zaria, Nigeria.

3. Corresponding author: chia28us@yahoo.com phytoplankton (Monastersky 1995) and constitute part of the sediment or bedrock materials of aquatic systems. They are not degradable but can be bioaccumulated along the food chain, transformed or complexed from one form to another in aquatic systems (Rai et al. 1981, Sunda et al. 2005). Human activities around the catchment affect the concentration of trace elements in ponds, thereby rising the levels sometimes beyond tolerable for some aquatic organisms. The extent to which microalgal species can tolerate trace metals makes them potential indicators for the presence and levels of these metals. Trace elements act as micronutrients at low concentrations, while at high concentrations they become toxic. Chlorococcum sp. is sensitive to zinc and mercury (Palmer 1969), Hormidium sp. is sensitive to copper (Hargreaves \& Whitton 1976), and Stigeoclonium sp. to zinc and cobalt (Pawlik-Skowronska et al., 1999). 
Other physicochemical factors like $\mathrm{pH}$, alkalinity, water hardness and macronutrient concentration determine which species or group thrives in a pond ecosystem (Sipaúba-Tavares et al. 2010).

On a general note, studies focusing on algae from small static water bodies are less reported compared to larger lenthic water bodies. Published works on green algae and other phytoplankton groups from artificial ponds from northern Nigeria are very scarce. A few generalized studies on the pond ecosystems in Nigeria include: Ado et al. (2004) on phytoplankton from burrow pit ponds in Kano; Mustapha \& Omotosho (2002) on a temporary pond in Ilorin; Bwala \& Omoregie (2009) on fish ponds in Jos; Adeogun et al. (2005) on fish ponds in Ibadan; and Chia et al. (2009a, b, 2011a, b) on other phytoplanktonic groups in ponds in Zaria.

This study attempts to provide more insight into the green algae and their relationship to physicochemical parameters in artificial ponds in Zaria, northern Nigeria.

\section{Material and method}

Study area - Four manmade ponds in Zaria $\left(11^{\circ} 04^{\prime} 50^{\prime \prime} \mathrm{N}\right.$ and $7^{\circ} 42^{\prime} 58^{\prime \prime}$ E) Nigeria were investigated. Some characteristics of these ponds are: Danmika Pond with 1.59 hectares area, $11^{\circ} 05^{\prime} 39.35^{\prime} \mathrm{N}$ and $7^{\circ} 41^{\prime} 28.99^{\prime} \mathrm{E}$, and $648 \mathrm{~m}$ elevation; Mairabo Pond with 3.69 hectares area, of $11^{\circ} 05^{\prime} 40.73^{\prime} \mathrm{N}$ and $7^{\circ} 41^{\prime} 32.33^{\prime} \mathrm{E}$, and 647 m elevation; Kabama Pond with 3.65 hectares area, $11^{\circ} 05^{\prime} 57.56^{\prime} \mathrm{N}$ and $7^{\circ} 41^{\prime} 23.55^{\prime} \mathrm{E}$, and $642 \mathrm{~m}$ elevation; and Aviation Quarry pond with 0.52 hectare area, $11^{\circ} 08^{\prime} 24.38^{\prime} \mathrm{N}$ and $7^{\circ} 40^{\prime} 55.86^{\prime} \mathrm{E}$, and $670 \mathrm{~m}$ elevation. The first three ponds are located at Dan Magaji along ZariaKano express way and lying within $2.5 \mathrm{~km}$ of each other. The Aviation Quarry Pond is located opposite the Nigerian College of Aviation Technology. These ponds are seasonal in nature, usually containing water for about 8-9 months per year i.e. from May of each year on. Danmika, Mairabo and Kabama ponds were formed from the excavations of top soils for use in road construction. The third pond was formed as a result of mining activities. The location of the pond is ravaged by stone mining for construction purposes. All the four ponds serve as important sources of water for drinking (to animals and man), washing, bathing and irrigating farmlands. Farmlands surround the first three ponds Aviation Quarry Pond is surrounded by domestic and small scale industrial structures.

Sampling and analysis of green algal samples - Samples were collected from four sampling stations in each pond from November 2005 to January 2006 (dry months), and from June to August 2006 (wet months). Water samples were collected at about $30 \mathrm{~cm}$ depth and one meter away from the shore at each sampling station (APHA 1998).
Glass jars $(100 \mathrm{~mL})$ were used to collect samples for algal analysis and dark brown glass bottles $(250 \mathrm{~mL})$ for $\mathrm{pH}$, dissolved oxygen (DO) and electrical conductivity (EC) analyses. Polyethylene bottles were used for collection and storage of water samples for other chemical analyses. All samples for chemical analysis were either analyzed immediately or stored at $-20^{\circ} \mathrm{C}$. Samples for green algae analysis were collected using a cone shaped, silk bolting cloth net of $20 \mu \mathrm{m}$ mesh size, a mouth radius of $20 \mathrm{~cm}$ and a $50 \mathrm{~mL}$ concentration bottle. The $50 \mathrm{~mL}$ concentrates were transferred to separately labeled $100 \mathrm{~mL}$ glass jars and fixed immediately with Lugol solution to preserve green algal cells (APHA 1998). Treatment and analysis of algal samples were done according to the procedures of Prescott (1977) and APHA (1998). Direct microscopic cell counts using the drop count technique (Bartram \& Rees 2000) was used to determine the green algal cell density (no of cells per $\mathrm{mL}$ ). Briefly, a drop of the concentrate was placed on a glass slide and the total number of individuals in that drop counted. Prior to these counts, the glass dropper used was calibrated to determine the number of drops that gave one milliliter.

Analyses of physicochemical parameters - Water temperature $\left({ }^{\circ} \mathrm{C}\right)$ readings were taken in situ using a mercury thermometer. Total dissolved solids (TDS), $\mathrm{pH}$ and EC (eletrical conductivity) were measured using a portable Hanna $\mathrm{pH} / \mathrm{EC} /$ TDS/temperature meter (model no H1991300). The modified Winkler azide method (Lind 1979, APHA 1998) was used to determine DO and biochemical oxygen demand (BOD). Total hardness and phenolphthalein alkalinity were determined using the procedure of Lind (1979) and APHA (1998). Nutrient concentrations (phosphate-phosphorus, $\mathrm{PO}_{4}-\mathrm{P}$; and nitratenitrogen, $\mathrm{NO}_{3}-\mathrm{N}$ ) were determined spectrophotometrically using a HACH DR/2000 direct reading spectrophotometer. Specific nutrient concentrations were read from calibration curves (Mackereth 1963, Lind 1979, APHA 1998).

Elemental analysis - Total trace metal composition and concentration of the water samples were determined using energy dispersive $\mathrm{x}$-ray fluorescence (EDXRF) spectrometry at the Center for Energy Research and Technology (CERT), Ahmadu Bello University, Zaria, Nigeria. Measurements were performed using an annular $25 \mathrm{mCi}{ }^{109} \mathrm{Cd}$ as the excitation source, that emits $\mathrm{Ag}-\mathrm{K} \mathrm{X}$-rays $[22.1 \mathrm{KeV}]$ in which case all elements with lower characteristics excitation energies were accessible for detection in the samples (Funtua 1999a, b). The system is further equipped with a $\mathrm{Si}(\mathrm{Li})$ detector having a resolution of $170 \mathrm{eV}$ for the $5.90 \mathrm{KeV}$ line, coupled to a computer controlled ADCcard. Quantitative processing of the samples was done by the emission transmission (E-T) method (Bernasconi et al. 1996, Kump 1996, Leroux \& Mahmoud 1996). Thick pure metal foils were used for sensitivity calibration of the system ( $\mathrm{Ti}, \mathrm{Fe}, \mathrm{Co}, \mathrm{Ni}, \mathrm{Cu}, \mathrm{Zn}, \mathrm{Zr}, \mathrm{Nb}, \mathrm{Mo}$, $\mathrm{Sn}, \mathrm{Ta}, \mathrm{Pb})$ and stable chemical compounds $\left(\mathrm{K}_{2} \mathrm{CO}_{3}, \mathrm{CaCO}_{3}\right.$, $\mathrm{Ce}_{2} \mathrm{O}_{3}, \mathrm{WO}_{3}, \mathrm{ThO}_{2}, \mathrm{U}_{3} \mathrm{O}_{8}$ ). Sample spectra were collected for $3000 \mathrm{~s}$ with the ${ }^{109} \mathrm{Cd}$ source and their evaluation done with the AXIL-QXAS program (Bernasconi 1996). 
Data analysis - Diversity indices were calculated using PAST for windows statistical software (Hammer et al. 2001). These involved Shannon diversity index (Shannon 1948); Simpson's dominance index (Simpson 1949); and Pielou's species evenness index (Pielou 1966).

Multivariate analyses were used (1) to identify environmental parameters that were most strongly associated with each other, and (2) to define environmental factors to phytoplankton species associations. Principal component analysis (PCA) (Ter Braak 1986) was used to identify trends between highly correlating physicochemical parameters. Afterwards, the possible relationship between physicochemical parameters and green algae from the ponds were subjected to canonical correlation analysis (CCorA). A CCorA finds two sets of basis vectors, one for $\mathrm{x}$ and the other for $\mathrm{y}$, such that the correlation between the projections of the variables onto these basis vectors are mutually maximized (Hotelling 1936). Ordination analyses (PCA and CCorA) were carried out using XLSTAT-ADA software for windows.

Temporal and spatial difference of mean physicochemical parameters and metal concentrations were determined using a two analysis of variance (ANOVA) at 5\% significance level.

\section{Results}

Eletrical conductivity (EC) of the ponds increased gradually in the dry months with the highest value of $429.5 \mu \mathrm{S} \mathrm{cm}^{-1}$ in January for Aviation Quarry Pond. From June 2006, EC declined to the lowest value of $60 \mu \mathrm{S} \mathrm{cm}^{-1}$ for Kabama Pond in August (figure 1). Changes in EC observed were significantly different $(P<0.05)$ between the study ponds (table 1$)$. Variations in TDS were similar to those observed for EC. Aviation Pond also had the highest amount of dissolved solids. The highest TDS (209 $\mathrm{mg} \mathrm{L}^{-1}$ ) was recorded in January for Aviation Quarry Pond. However, higher values were recorded in the wet months when compared to the dry months (figure 1). Values of $\mathrm{pH}$ in these ponds fell within a range of 5.9-8.3 (figure 1). Throughout this study, the water temperature values ranged from 26.9 $-28.7^{\circ} \mathrm{C}$ in all ponds. The lowest value $\left(25.9^{\circ} \mathrm{C}\right)$ was recorded in November 2005 for Danmika Pond (figure 1). The highest DO concentration recorded $\left(5.35 \mathrm{mg} \mathrm{L}^{-1}\right)$ was for Danmika Pond in December. Lower dissolved oxygen values were observed in the dry months than the wet months (figure 1). Although, the highest BOD concentration $\left(1.70 \mathrm{mg} \mathrm{L}^{-1}\right)$ was observed in August 2006 for Kabama Pond, higher values were recorded in the dry months (figure 1). Alkalinity and water hardness significantly differed between the studied ponds. However, only water hardness showed significant monthly variation throughout this study (table 1). There was a general increase in alkalinity from November to December and then a decrease observed in Mairabo and Kabama ponds in January. In Aviation Quarry Pond, the highest value $\left(17.0 \mathrm{mg} \mathrm{L}^{-1}\right)$ for the whole study was recorded in January (figure 1). Water hardness on the other hand had higher values during the wet months than in the dry months. The highest value of $5.0 \mathrm{mg} \mathrm{L}^{-1}$ was recorded in Aviation Quarry Pond in June (figure 1). Analysis of variance showed that there was significant difference between ponds and months for nitrate concentration (table 1). Higher nitrate concentrations were recorded in the dry months than in the wet months, while higher phosphate concentrations were observed in the wet months (figure 1).

The concentration and distribution of trace elements over time in the different ponds are shown in figure 2. All the trace elements except cobalt analyzed had higher concentrations in the dry months. Cobalt concentration increased and decreased over time without having a defined pattern. The concentrations of copper, arsenic and zinc significantly $(P<0.05)$ varied from month to month, while those of nickel and

Table 1. Results of ANOVA analyses for physicochemical parameters and metals analyzed in the selected ponds. (TDS = total dissolved solids; EC = electrical conductivity; $\mathrm{DO}=$ dissolved oxygen; Water Temp $=$ water temperature; $\mathrm{BOD}=$ biochemical oxygen demand; $\mathrm{PO}_{4}-\mathrm{P}=$ phosphate phosphorus; $\mathrm{NO}_{3}-\mathrm{N}=$ nitrate nitrogen).

\begin{tabular}{lccllc}
\hline & \multicolumn{2}{c}{ Ponds } & & \multicolumn{2}{c}{ Months } \\
\cline { 2 - 3 } \cline { 5 - 6 } & F value & P value & & F value & P value \\
\hline BOD & 2.01 & 0.16 & & 1.69 & 0.20 \\
Alkalinity & $5.24^{*}$ & 0.01 & & 1.66 & 0.20 \\
Water hardness & $3.96^{*}$ & 0.03 & & $6.91^{*}$ & 0.00 \\
$\mathrm{PO}_{4}-\mathrm{P}$ & 0.73 & 0.55 & & 1.75 & 0.18 \\
$\mathrm{NO}_{3}$-N & 3.09 & 0.06 & & $2.90^{*}$ & 0.05 \\
$\mathrm{DO}$ & 1.86 & 0.18 & & 0.36 & 0.87 \\
$\mathrm{Water}$ temp & 1.13 & 0.37 & & 0.69 & 0.64 \\
$\mathrm{EC}$ & $6.19^{*}$ & 0.01 & & 0.98 & 0.46 \\
$\mathrm{pH}$ & 1.96 & 0.16 & & 1.83 & 0.17 \\
$\mathrm{TDS}$ & 2.00 & 0.16 & & 0.18 & 0.97 \\
$\mathrm{Mn}$ & 1.02 & 0.41 & & 2.06 & 0.13 \\
$\mathrm{Co}$ & 1.85 & 0.18 & & 1.60 & 0.22 \\
$\mathrm{Ni}$ & 1.95 & 0.17 & & $3.72^{*}$ & 0.02 \\
$\mathrm{Cu}$ & 1.50 & 0.26 & & $4.17^{*}$ & 0.01 \\
$\mathrm{Zn}$ & 1.31 & 0.31 & & $4.25^{*}$ & 0.01 \\
$\mathrm{As}$ & 1.47 & 0.26 & & $6.88^{*}$ & 0.00 \\
$\mathrm{~Pb}$ & 1.41 & 0.28 & & $6.23^{*}$ & 0.00 \\
$\mathrm{Fe}$ & 1.91 & 0.17 & & 1.07 & 0.41 \\
\hline
\end{tabular}

* Significant at $P<0.05$. 


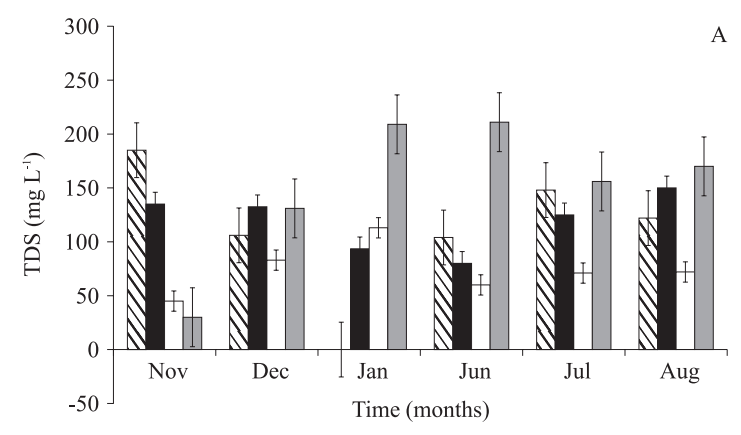
A
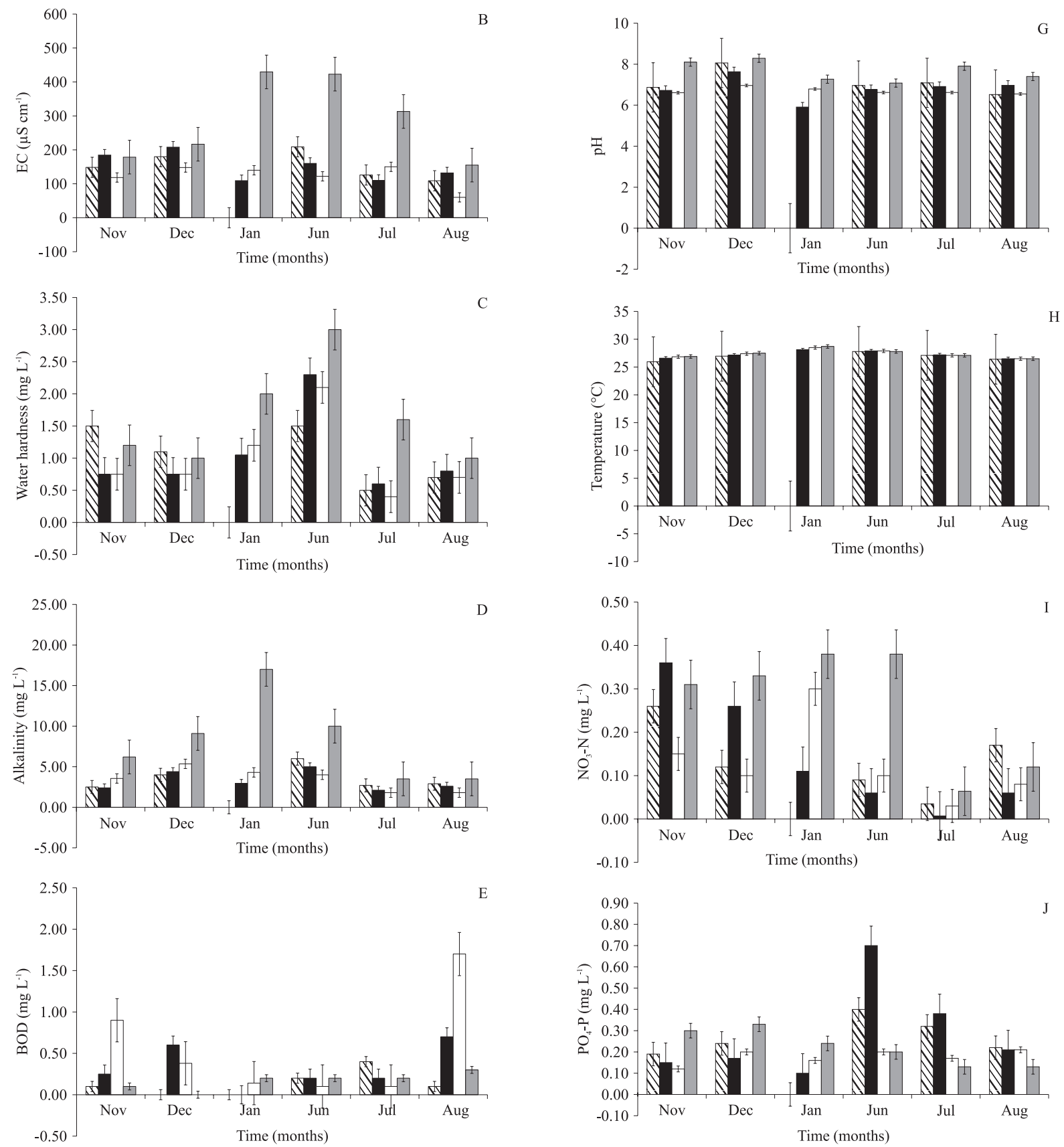

Figure 1. Temporal and spatial variation of (a) total dissolved solids (TDS); (b) electrical conductivity (EC); (c) water hardness; (d) alkalinity; (e) biochemical oxygen demand (BOD); (f) dissolved oxygen (DO); (g) pH; (h) temperature; (i) nitrate $\left(\mathrm{NO}_{3}\right.$ $\mathrm{N}$ ); (j) phosphate $\left(\mathrm{PO}_{4}-\mathrm{P}\right)$ of the studied ponds in Zaria, Nigeria. Bars represent standard error for $n=4$. ( $\mathbb{N}=$ Danmika pond; $\boldsymbol{\square}=$ Mairabo pond; $\square=$ Kabama pond; $\square=$ Aviation quarry pond). 

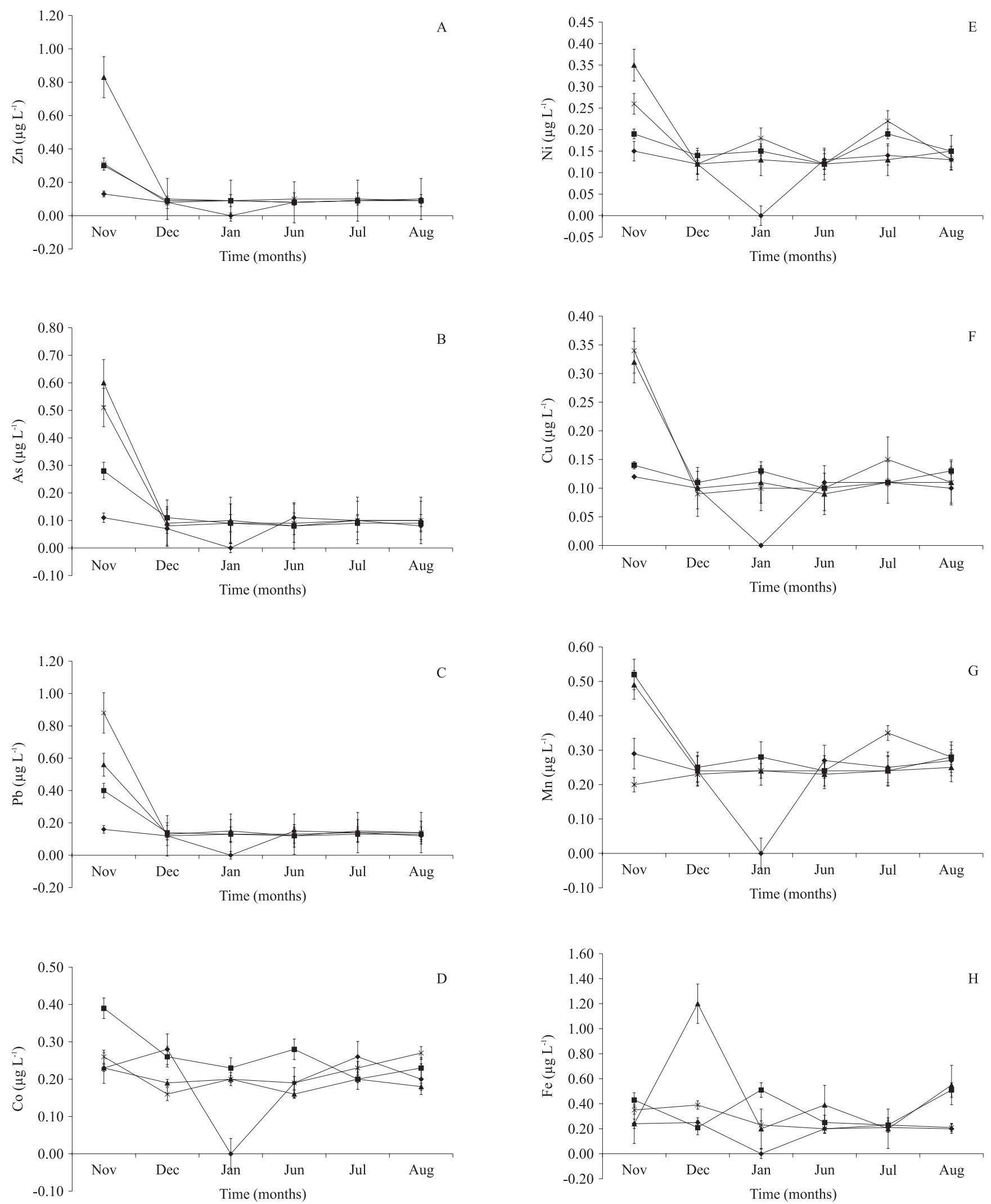

Figure 2. Changes in (a) Zinc (ZN); (b) Arsenic (As); (c) Lead (Pb); (d) Cobalt (Co); (e) Nickel (Ni); (f) Copper (Cu); (g) Manganese (Mn); (h) Iron (Fe) concentrations of the studied ponds. Bars represent standard error for $n=4$. $(\bullet-=$ Danmika pond; $-=$ Mairabo pond; $\boldsymbol{-}=$ Kabama pond; $\boldsymbol{*}=$ Aviation quarry pond). 
lead significantly varied both temporally and spatially (table 1). The relationship between trace elements and physicochemical parameters using PCA showed that the contributions of most trace elements were distinct from those of the physicochemical parameters (figure 3). The highest eigen values recorded were for $\operatorname{Mn}(0.33)$, $\mathrm{Ni}(0.35)$ and Mo (0.36) to the first (F1) axis and Zn $(-0.26)$ to the second (F2) axis. For physicochemical parameters, the highest contributions to the $\mathrm{F} 1$ axis in terms of eigen values were by $\mathrm{pH}(0.30)$, temperature $(0.30)$, alkalinity $(0.11)$ and nitrate nitrogen $(0.19)$, while to the F2 axis TDS (0.38), EC (0.41), alkalinity (0.38), water hardness (0.36) and nitrate nitrogen $(0.24)$ had the highest contributions (figure 3 ). The first and second axis of the PCA contributed to $56 \%$ of the total variation observed throughout the study.

A total of 27 green algal species divided into 16 families were recorded (table 2). Stichococcus bacillaris was found to have the highest relative abundance $(65 \%)$ in all the ponds. With 50\%, Haematococcus lacustris was next to Stichococcus bacillaris in abundance. The abundance of the remaining species was within the range of 12.5 to $37.5 \%$ in all the ponds. Diversity indices analyses of green algae from these ponds showed that Kabama Pond had the highest dominance index of 0.23 , while Danmika Pond had the lowest dominance index of 0.14 . Shannon diversity index analysis showed that Danmika Pond had the highest value of 2.39 while in Kabama Pond the least value of 1.75 was observed. Species evenness values ranged from 0.56 to 0.64 in all the ponds (table 3 ). Canonical correlation analysis of all the parameters analyzed showed that Closterium sp. and Rhizoclonium hookeri were closely positively associated with the concentration of $\mathrm{Fe}$ and sensitive to alkalinity, TDS and EC (figure 4). Stichococcus bacillaris, Staurastrum rotula and Sphaeroplea sp. had close positive association with BOD, Mn, and Mo levels in the water. These species were however sensitive to alkalinity and phosphate phosphorus concentration. Sensitivity here means that as the concentration or levels

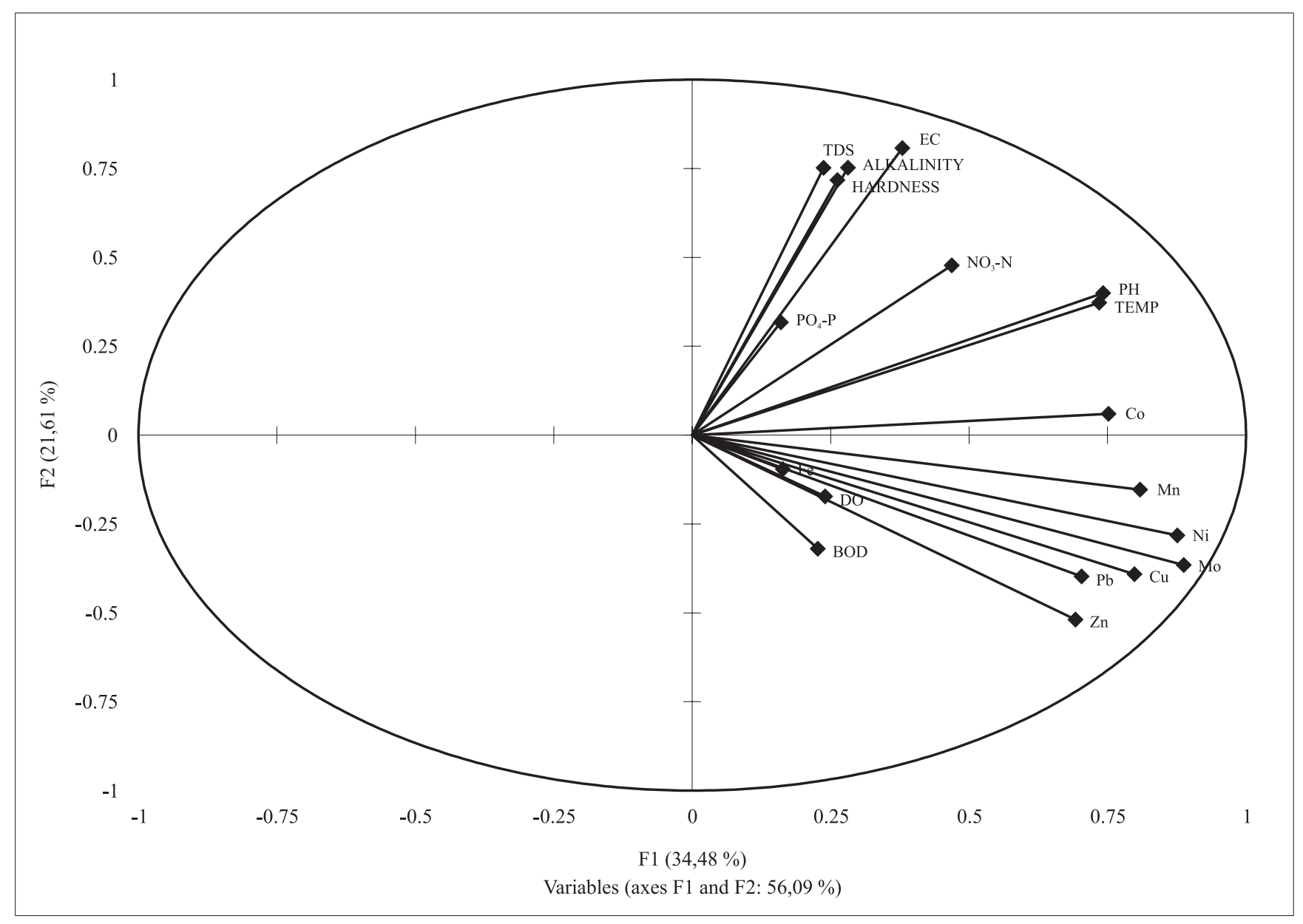

Figure 3. PCA analysis of the ten physicochemical parameters and eight metals analyzed for the selected ponds in Zaria, Nigeria. 
Table 2. Occurrence of green algal species in selected ponds in Zaria, northern Nigeria. $(-=$ absent; $+=$ sparse; $++=$ abundant; $+++=$ dominant; $\mathrm{RA}=$ relative abundance in percentage).

\begin{tabular}{|c|c|c|c|c|c|c|c|c|c|}
\hline & \multicolumn{4}{|c|}{ Dry months } & \multicolumn{5}{|c|}{ Wet months } \\
\hline & Danmika & Mairabo & Kabama & $\begin{array}{l}\text { Aviation } \\
\text { quarry }\end{array}$ & Danmika & Mairabo & Kabama & $\begin{array}{l}\text { Aviation } \\
\text { quarry }\end{array}$ & $\begin{array}{l}\text { RA } \\
(\%)\end{array}$ \\
\hline Chaetophoraceae & + & - & - & - & - & - & - & - & 12.5 \\
\hline $\begin{array}{l}\text { Draparnaldia glamerata } \text { (Vauch.) Ag. } \\
\text { Pseudouvella americana (Snow) } \\
\text { Wille. }\end{array}$ & ++ & - & - & - & - & - & - & - & 12.5 \\
\hline $\begin{array}{l}\text { Chloroangiaceae } \\
\text { Chlorangium stentorinum (Her.) Stein }\end{array}$ & + & + & - & - & - & - & - & - & 25.0 \\
\hline Cladophoraceae & + & - & - & - & - & - & - & - & 12.5 \\
\hline Dermatophyton radians Peter. & + & - & - & - & - & - & - & - & 12.5 \\
\hline $\begin{array}{l}\text { Pithophora oedogonia (Mont.) Wittr. } \\
\text { Rhizoclonium hookeri Kuetz. }\end{array}$ & ++ & + & - & - & - & - & - & - & 25.0 \\
\hline Desmidiaceae & - & - & ++ & - & + & - & + & - & 37.5 \\
\hline Closterium sp. & ++ & + & - & - & - & - & - & - & 25.0 \\
\hline Cosmarium panamense Presc. & - & +++ & - & - & - & - & - & - & 12.5 \\
\hline Micrasterias radiata Hass. & - & + & - & - & - & - & + & - & 25.0 \\
\hline $\begin{array}{l}\text { Staurastrum rotula Nordst. } \\
\text { Xanthidium cristatum Hass. }\end{array}$ & - & - & - & ++ & - & +++ & + & - & 37.5 \\
\hline $\begin{array}{l}\text { Endosphaeraceae } \\
\text { Rhodochytrium spilanthidis } \\
\text { Lagerheim }\end{array}$ & - & - & - & - & + & - & - & - & 12.5 \\
\hline $\begin{array}{l}\text { Eremosphaeraceae } \\
\text { Eremosphaera sp. }\end{array}$ & - & - & - & - & +++ & - & - & - & 12.5 \\
\hline $\begin{array}{l}\text { Gloeocystaceae } \\
\text { Palmellopsis gelatinosa Korsch }\end{array}$ & + & - & - & - & - & - & - & +++ & 25.0 \\
\hline $\begin{array}{l}\text { Haematococcaceae } \\
\text { Haematococcuslacustris (Girod.) } \\
\text { Rostaf. }\end{array}$ & - & - & +++ & - & ++ & + & - & ++ & 50.0 \\
\hline $\begin{array}{l}\text { Hydrodictyaceae } \\
\text { Hydrodictyon reticulatum (L.) } \\
\text { Lagerheim }\end{array}$ & - & + & - & + & - & - & - & - & 25.0 \\
\hline Oocystaceae & - & - & - & ++ & - & - & - & - & 12.5 \\
\hline Ankistrodesmusbraunii (Naegeli) & - & - & - & + & - & - & - & - & 12.5 \\
\hline Brunn. & +++ & + & - & - & - & - & - & - & 25.0 \\
\hline $\begin{array}{l}\text { Cerasterias irregulare G. M. Smith } \\
\text { Chlorella parasitica Brandt. } \\
\text { Selenastrum gracile Reinsch. }\end{array}$ & - & - & + & - & - & - & - & - & 12.5 \\
\hline $\begin{array}{l}\text { Phacotaceae } \\
\text { Pedinopera sp. }\end{array}$ & - & - & + & - & - & - & - & - & 12.5 \\
\hline $\begin{array}{l}\text { Polyblepharidaceae } \\
\text { Polyblepharides sp. }\end{array}$ & + & - & - & - & - & - & - & - & 12.5 \\
\hline Scenedesmaceae & ++ & - & - & - & - & - & - & - & 12.5 \\
\hline $\begin{array}{l}\text { Coelastrum microporum Naegeli. } \\
\text { Scenedesmus quadricauda (Turp.) } \\
\text { Bréb. }\end{array}$ & - & - & - & ++ & - & + & - & +++ & 37.5 \\
\hline $\begin{array}{l}\text { Sphaeropleaceae } \\
\text { Sphaeroplea sp. }\end{array}$ & + & - & - & - & - & - & ++ & + & 37.5 \\
\hline $\begin{array}{l}\text { Ulotrichaceae } \\
\text { Stichococcus bacillaris Naegeli }\end{array}$ & + & +++ & + & ++ & - & - & +++ & - & 65.5 \\
\hline $\begin{array}{l}\text { Volvocaceae } \\
\text { Volvox tertius Meyen. }\end{array}$ & - & - & ++ & + & - & - & + & - & 37.5 \\
\hline
\end{tabular}




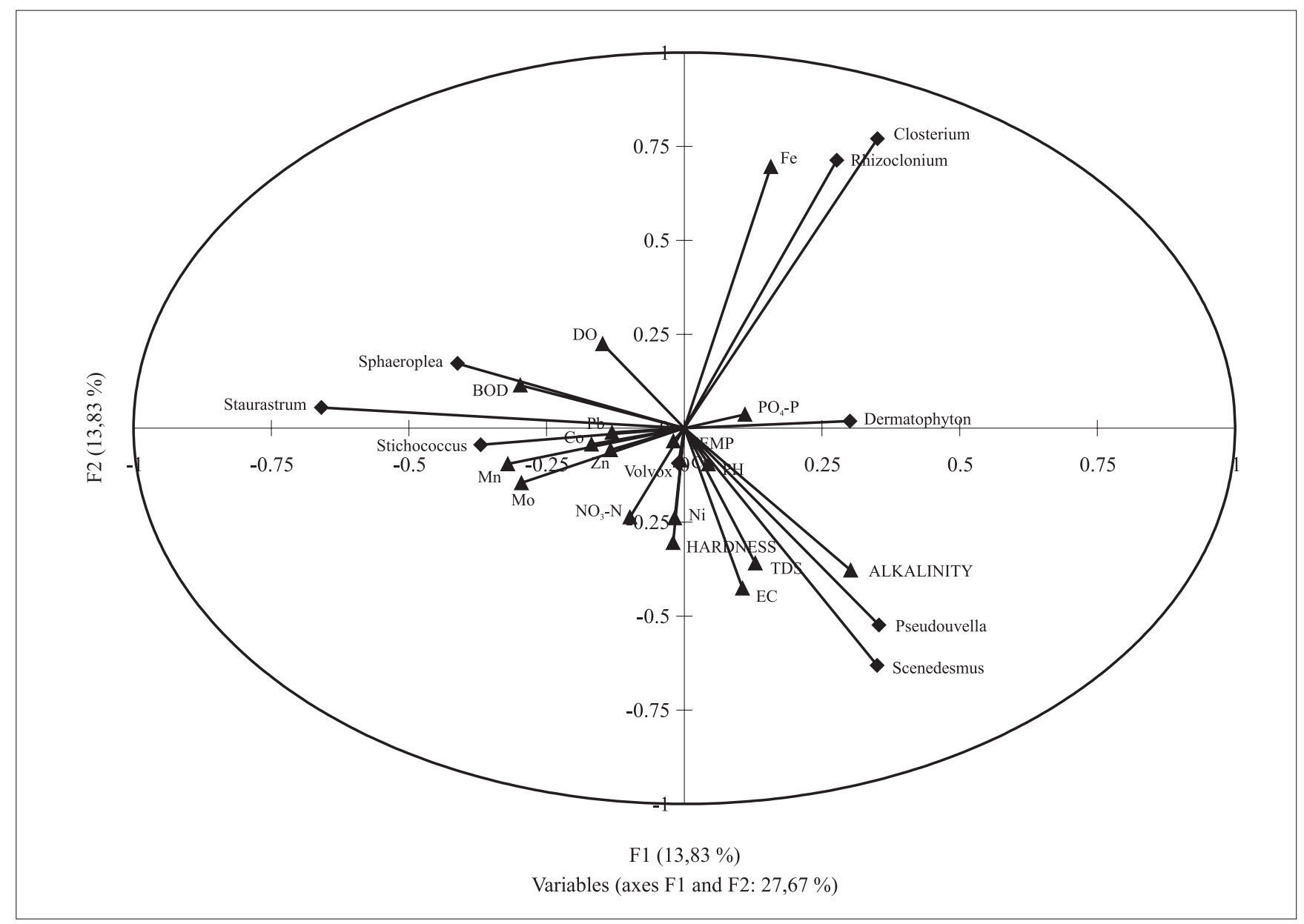

Figure 4. Canonical correlation analysis for the ten physicochemical parameters, eight metals and green algal species analyzed in the different ponds.

of the parameters increased or decreased, the number of individuals decreased or increased in the opposite direction to this variation. Pseudouvella americana and Scenedesmus quadricauda showed a positive association with alkalinity but were sensitive to Fe, BOD, Mn and Mo. The variations in the first two axis (cumulative eigen percentage) amounted to the $27.67 \%$ of the total variation observed for all parameters analyzed.

Table 3: Chlorophyta community structure indices for the different ponds studied

Water body

\section{Indices}

\begin{tabular}{lccc}
\hline & 0.14 & 2.39 & 0.61 \\
Danmika pond & 0.22 & 1.90 & 0.56 \\
Mairabo Pond & 0.23 & 1.75 & 0.64 \\
Kabama Pond & 0.21 & 1.92 & 0.62 \\
\hline
\end{tabular}

\section{Discussion}

Variations in TDS and EC in the ponds are common to other lenthic water bodies found in Zaria and northern Nigeria (Chia et al. 2009a, b, 2010). These changes may be linked to climatic conditions, and human activities around the catchment which range from surface runoff of fertilizers from neighboring farms and other substances from the catchment area. The $\mathrm{pH}$ values were mostly maintained between the optimum range (6.5-8.5) for most biological activities. The only shift from this trend was observed in January in Mairabo pond where the pond was slightly acidic, which may have harmful effect on non tolerant algal species. According to Stumn \& Morgan (1981) and Sunda et al. (2005), the correlation of $\mathrm{pH}$ and temperature with chromium, manganese, cobalt, nickel and copper could be attributed to the fact that the solubility and speciation of these metals in water are affected by them. Lower temperature values in the dry months are characteristic 
of the Harmattan season in northern Nigeria (Balarabe 2001), while resultant lower water volume in the ponds could be implicated for the increase temperatures in January. This is because most ponds were almost totally dried up at the end of this month. However, the values in the wet months did not significantly vary from those of the dry months. This finding agrees with those of Gobo (1988) and Chindah \& Pudo (1991) for equatorial tropical areas. The absence of rains and high rates of evaporation are factors that best explain the high alkalinity values in the dry months in all four ponds studied. Kabama and Aviation Quarry ponds had high alkalinity values and also hardness mainly due to the anthropogenic activities around the catchment and the nature of the bed rock material (Balarabe 2001). The concentrations of DO and BOD of these pond fall within the range reported from other ponds and standing water bodies in Zaria (Chia et al. 2009a). Differences in the amount of nutrients (phosphate-phosphorus and nitrate-nitrogen) in these ponds may be from differential rates of nutrients entering them throughout the year. The sources of these materials are mainly feces from grazing animals, mining activities, untreated sewage and fertilizers from surrounding farmlands.

The growth of microalgae is not dependent only on a sufficient provision of essential macronutrient elements but also on a number of micronutrient metals (Sunda et al. 2005). Among these micronutrients are iron, copper, molybdenum, manganese and zinc of which their total concentrations were determined. Their concentrations varied from month to month between the wet and dry months. This variation may be controlled by the volume of water present in these ponds per time, which controls the dilution rate. As water levels decrease from evaporation and lack of rainfall, the concentrations of these metals also increase. This is supported by the fact that in the dry months, the highest concentrations of these metals were recorded. Other researchers have also reported higher trace element concentrations in periods of low or no rainfall than the wet months (Olaifa et al. 2004, Nguyen et al. 2005, Igbal et al. 2006). The sufficiency or deficiency of these metals for algal cells depends on the requirement of a given algal species, cellular metal concentration and the aqueous form in which they are present (Peterson 1982, Bates et al. 1982, 1983, Parent \& Campbell 1994).

The changes in green algal populations in these ponds are as a result of their interactions with their physical, chemical and biological environment. The species that showed close association with the physicochemical conditions of the ponds may be useful tools for ecological water quality index analysis (Lacerda et al. 2004). Community analysis indices showed that species dominance was relatively low throughout this study in all the ponds. This is because the highest value recorded in this study was 0.23 in Kabama Pond, which means that no single species consistently had higher abundance than that the rest species. In addition, this is supported by the Shannon diversity index having an average value of two. The distribution of species in these ponds was relatively even. The values obtained in this study were on the high side. The community indices analysis of the green algal community structure shows that environmental conditions within these ponds were generally favorable to them (Rueda et al. 2002). Canonical correlation analysis implicated the trace elements as having the most significant association with some green algae species recorded in this study. Our results show that while some species could tolerate and thrive at certain levels of some physicochemical parameters, others showed sensitivity to the same parameters at these levels. The environmental requirements of different species differ, hence defining how they respond to variations in these factors. Le Jeune et al. (2006) reported that copper concentration in natural phytoplankton showed community structure and composition effects that were depended on season in which they were applied. They showed marked differential effects between spring and summer. These metals serve important metabolic purposes ranging from photosynthetic electron transport, respiratory electron transport, nitrate and nitrite reduction, sulfate reduction, dinitrogen fixation and detoxification of reactive oxygen species (Rueter \& Ades 1987, Boyd et al. 2000, Sunda 2001, He et al. 2010).

Our study has shown that the occurrence and abundance of green algae species in these ponds are closely linked to their physicochemical characteristics. In addition, most parameters analyzed showed specific temporary and/or spatial variation.

\section{References}

ADEOGUN, O.A., FAFIOYE, O.O., OLALEYE, B.A. \& NGOBILI, G.O. 2005. The relationship between some physicochemical parameters and plankton composition on fish production in ponds. In the 19th annual conference of the Fisheries Society of Nigeria (FISON), Ilorin, Nigeria.

ADO, I.Y., ADIKWU, I.A. \& ABDULLAHI, B.A. 2004. studies on limnological parameters and phytoplankton dynamics in some borrow pit ponds in Kano Metropolitan area, Nigeria. Best Journal 1:124-133. 
APHA - American Public Health Association. 1998. Standard methods for the examination of water and wastewater. $20^{\text {th }}$ Edition. American Water Works Association/Water Environmental Federation, Washington.

BALARABE,M.L.2001.Effect of limnologicalcharacteristics on zooplankton composition and distribution in Dumbi and Kwangila ponds Zaria, Nigeria. Phd Thezis, Department of Biological Sciences, Ahmadu Bello University, Zaria.

BARTRAM, J. \& REES, G. 2000. Monitoring bathing waters A practical guide to the design and implementation of assessments and monitoring programmes. World Health Organisation, Boundary Row, London.

BATES, S.S., TESSIER, A., CAMPBELL, P.G.C. \& BUFFLE, J. 1982. Zinc adsorption and transport by Chlamydomonas variabilis and Scenedesmus subspicatus (Chlorophyceae) grown in semicontinuous culture. Journal of Phycology 18:521-529.

BATES, S.S., LETOURNEAU, M., TESSIER, A. \& CAMPBELL, P.G.C. 1983. Variation in zinc adsorption and transport during growth of Chlamydomonas variabilis (Chlorophyceae) in batch culture with daily addition of zinc. Canadian Journal of Fisheries and Aquatic Sciences 40:895-904.

BERNASCONI, G. B. 1996. AXIL-QXAS, Instruction Manual. IAEA, Vienna.

BERNASCONI, G.B., BAMFORD, S.A., DOSAN, B., HASELBERGER, N., MARKOWICZ,A., MAHMOUD, A. \& VALCOVIC, V. 1996. Applicability of annular source excited systems in quantitative XRF analysis. X-ray Spectrom 23:65-70.

BOYD, P.W., WATSON, A.J., LAW, C.S., ABRAHAM, E.R., TRULL, T., MURDOCH, R., BAKKER, D.C.E., BOWIE, A.R., BUESSELER, K.O., CHANG, H., CHARETTE, M., CROOT, P., DOWNING, K., FREW, R., GALL, M., HADFIELD, M., HALL, J., HARVEY, M., JAMESON, G., LAROCHE, J., LIDDICOAT, M., LING, R., MALDONADO, M.T., MCKAY, R.M., NODDER, S., PICKMERE, S., PRIDMORE, R., RINTOUL, S., SAFI, K., SUTTON, P., STRZEPEK, R., TANNEBERGER, K., TURNER, S., WAITE, A. \& ZELDIS, J. 2000. A mesoscale phytoplankton bloom in the polar Southern Ocean stimulated by iron fertilization. Nature 407:695-702.

BWALA, R.L. \& OMOREGIE, E. 2009. Organic enrichment of fish ponds: application of pig dung vs tilapia yield. Pakistan Journal of Nutrition 8:1373-1379.

CHIA, A.M., ABOLUDE, D.S., LADAN, Z., AKANBI, O. \& KALABOMS, A. 2009a. The presence of microcystins in aquatic ecosystems in northern Nigeria: Zaria as a case study. Research Journal of Environmental Toxicology 3:170-178.

CHIA, A.M., ONIYE, S.J., LADAN, Z., LADO, Z., PILA, E.A., INEKWE, V.U., MMEROLE, J.U. 2009b. A survey for the presence of microcystins in aquaculture ponds in Zaria, Northern-Nigeria: Possible public health implication. African Journal of Biotechnology 8:6282-6289.
CHIA, A.M., BAKO, S.P., ALONGE, S., \& ADAMU, A.K. 2011a. Records of diatoms and physicochemical parameters of seasonal ponds in Zaria, Northern Nigeria. West African Journal of Applied Ecology 18:79-93.

CHIA, A.M., IORTSUUN, D.N., STEPHEN, B.J., AYOBAMIRE, A.E., \& LADAN, Z., $2011 \mathrm{~b}$. Phytoplankton responses to changes in macrophyte density in a tropical artificial pond in Zaria, Nigeria. African Journal of Aquatic Sciences 36:34-46.

CHINDAH, A.C. \& PUDO, J. 1991. A preliminary checklist of algae found in plankton of Bonny River in Niger Delta, Nigeria. Fragmenta Floristica Geobotamoca Polonica 36:112-126.

FUNTUA, I.I. 1999a. Analysis of Nb-Ta ores by energy dispersive X-ray fluorescence spectrometry. Journal of Trace Microprobe Technology 17:189-195.

FUNTUA, I.I. 1999b. Application of the transmission emission method in EDXRF for the determination of trace elements in geological and biological materials. Journal of Trace Microprobe Technology 17:293-297.

GOBO, A.E. 1988. Relationship between rainfall trends and flooding in the Niger Delta-Benue River Basin. Journal of Meteorology 13:220-224.

HAMMER, Ø., HARPER, D.A.T. \& RYAN, P.D. 2001. PAST: Paleontological statistics software package for education and data analysis. Palaeontologia Electronica 4:1-9.

HARGREAVES, J.W. \& WHITTON, B.A. 1976. Effect of pH on tolerance of Hormidium rivulare to zinc and copper. Oecologia 26:235-243

HE, H., CHEN, F., LI, H., XIANG, W., LI, Y. \& JIANG, Y. 2010. Effect of iron on growth, biochemical composition and paralytic shellfish poisoning toxins production of Alexandrium tamarense. Harmful Algae 9:98-104.

HOTELLING, H. 1936. Relations between two sets of variates. Biometrika 28:321-377.

IQBAL, F., RAZA, N., ALI, M. \& ATHAR, M. 2006. Contamination of Kallar Kahar Lake by inorganic elements and heavy metals and thier temporal variations. Journal of Applied Sciences and Environmental Management 10:95-98.

KUMP, P. 1996. QAES: Quantitative Analysis of Environmental Samples. Instruction Manual. Editora Ljubljana, Slovenia.

LACERDA, S.R., KOENING, M.L., NEUMANN-LEITAO, S. \& FLORES-MONTES, M.J. 2004. Phytoplankton nyctemeral variation at a tropical river estuary (Itamaracá - Pernambuco - Brazil. Brazilian Journal of Biology 64:81-94.

LEROUX, J. \& M. MAHMOUD, M. 1996. X-ray quantitative analysis by an emission- transmission, method. Analytical Chemistry 38:76-82.

LE JEUNE, A., CHARPIN, M., DELUCHAT, V., BRIAND, J., LENAIN, J., BAUDU, M. \& AMBLARD, C. 2006. Effect of copper sulphate treatment on natural phytoplanktonic communities. Aquatic Toxicolology 80:267-280. 
LIND, O.T. 1979. A handbook of limnological methods. CV Mosby Co, St. Louis.

MACKERETH, F.J.H. 1963. Some methods of water analysis for liminologist scientist Freshwater Biology Association Publication, city.

MONASTERSKY, R. 1995. Iron versus the greenhouse: oceanographers cautiously explore a global warming therapy.. Science News 148:220-222.

MUSTAPHA, M.K. \& OMOTOSHO, J.S. 2002. An ecological study of a temporary pond in Ilorin, Kwara state, Nigeria. Bioscience Research Communications 14:165-174.

NGUYEN, H.L., LEERMAKERSA, M., OSAN, J., TOROK, S. \& BAEYENSA, W. 2005. Heavy metals in Lake Balaton: water column, suspended matter, sediment and biota. Science of the Total Environment 340:213-230.

OLAIFA, F.E., OLAIFA, A.K., ADELAJA, A.A. \& OWOLABI, A.G. 2004. Heavy metal contamination of Clarias gariepinus from a lake and fish farm in Ibadan, Nigeria. African Journal of Biomedical Research 7:145148.

PALMER, C.M. 1969. A composite rating of algae tolerating organic pollution. Journal of Phycology 15:78-82.

PARENT, L. \& CAMPBBELL, P.G.C. 1994. Aluminium bioavailability for the green alga Chlorella pyrenoidosa in an acidified synthetic soft water. Environmental Toxicology and Chemistry 13:587-598.

PAWLIK-SKOWRONSKA, B., PIRSZEL, J., \& SKOWRONSKI, T. 1999. Changes in the phytochelation levels in the freshwater green alga Stigeoclonium tenue exposed to heavy metal mixture at different pHs, bicarbonate and suspended matter content. In Proceedings of the International Conference on the Biogeochemistry of Trace Elements Research, International Society for Trace Element Research, Vienna, p.1168-1169.

PETERSON, R. 1982. Influence of copper and zinc on the growth of a freshwater alga Scenedesmus quadricuada: the significance of chemical speciation. Environmental Science and Technology 18:443-447.
PIELOU, E.C. 1966. The measurement of diversity in different types of biological collections. Journal of Theoretical Biology 13:131-144.

PRESCOTT, G.W. 1977. The fresh water algae. WMC Brown Company Publishers, Dubuque.

RAI, L.C., GAUR, J.P. \& KUMAR, H.D. 1981. Phycology and heavy metal pollution. Biological Reviews 56: 99-151.

RUEDA, J., CAMACHO, A., MEZQUITA, F., HERNANADEZ, R. \& ROCA, J.R. 2002. Structure in some southern english streams: the influence of physicochemical factors. Freshwater Biology 13:521544.

RUETER, J.G. \& ADES, D.R. 1987. The role of iron nutrition in photosynthesis and nitrogen assimilation in Scenedesmus quadricauda (Chlorophyceae). Journal of Phycology 23:452-457.

SHANNON, C.E. 1948. A mathematical theory of communication. Bell System Technical Journal 27:379423.

SIMPSON, E.H. 1949. Measurement of diversity. Nature 163:688-688.

SIPAÚBA-TAVARES, L.H., MILLAN, R.N. \& AMARAL, A.A. 2010. Influence of management on plankton community of fishponds during the dry and rainy seasons. Acta Limnologica Brasiliensia, 22:70-79.

STUMM, W. \& MORGAN, J.J. 1981. Aquatic chemistry: An introduction emphasizing chemical equilibrium in natural water. J Wiley and Sons, New York.

SUNDA, W.G. 2001. Bioavailability and bioaccumulation of iron in the sea. In The Biogeochemistry of iron in seawater (D.R. Turner \& K.A. Hunter, eds.). John Wiley \& Sons, New York, p.41-84.

SUNDA, W.G., PRICE, N.M. \& MOREL, F.M.M. 2005. Trace metal ion bufferes and their use in culture studies. In Algal Culturing Techniques (R.A. Andersen, ed.). Elsevier Academic Press, London, p.35-64.

TER BRAAK, C.J.F. 1986. Canonical correspondence analysis: a new eigenvector technique for multivariate direct gradient analysis. Ecology 67:1167-1179. 
